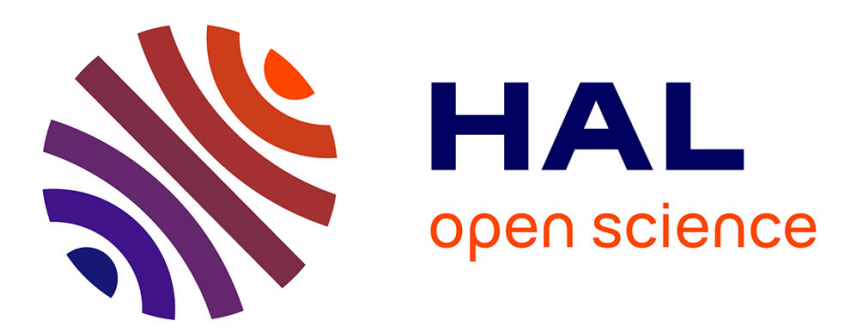

\title{
Cooper-graphite composite material for application to sliding electrical contacts
}

\author{
S. Emmer, J. Bielek, A. Havalda
}

\section{To cite this version:}

S. Emmer, J. Bielek, A. Havalda. Cooper-graphite composite material for application to sliding electrical contacts. Journal de Physique IV Proceedings, 1993, 03 (C7), pp.C7-1799-C7-1804. 10.1051/jp4:19937285 . jpa-00251927

\section{HAL Id: jpa-00251927 https://hal.science/jpa-00251927}

Submitted on 1 Jan 1993

HAL is a multi-disciplinary open access archive for the deposit and dissemination of scientific research documents, whether they are published or not. The documents may come from teaching and research institutions in France or abroad, or from public or private research centers.
L'archive ouverte pluridisciplinaire HAL, est destinée au dépôt et à la diffusion de documents scientifiques de niveau recherche, publiés ou non, émanant des établissements d'enseignement et de recherche français ou étrangers, des laboratoires publics ou privés. 


\title{
Cooper-graphite composite material for application to sliding electrical contacts
}

\author{
Š. EMMER, J. BIELEK ${ }^{*}$ and A. HAVALDA \\ Slovak Technical University, Faculty of Mechanical Engineering, The Slovak Republic \\ ${ }^{*}$ Faculty of Electrical Engineering, Bratislava, The Slovak Republic
}

\begin{abstract}
Various requirements are laid on the sliding electrical contacts carrying electrical current between the stationary and rotating parts of e.g. electromotors, generators, seam welding machines. Special requirements are laid on the properties of these contacts, particulary on their electrical and thermal conductivity, wear resistance, etc. For high voltage and low current densities it is possible, e.g. in electromotors, to employ all-carbon or allgraphite sliding contacts which exhibit the sufficient electrical conductivity and superior sliding properties. In the case of low voltage and high current densities, typical for eg. seam welding machines, it is reasonable to employ materials with high specific electrical conductivity, satisfactory thermal conductivity and low friction coefficient. Such conditions are best fulfilled by composite material composed of matrix showing high electrical conductivity, while graphite in the form of particles, fibres and the like creates the secondary phase in the matrix, which ensures high sliding properties. Generally the materials referred to as metal graphites in the field of electrical engineering are concerned. The nominal chemical composition of metal graphites covers typically the following ranges: graphite-5 to $70 \%, \mathrm{Sn}-0$ to $10 \%, \mathrm{~Pb}-0$ to $12 \%$, balance- $\mathrm{Cu}$. To obtain the materials falling in this group is possible only by powder metallurgy because certain components of the given composites are mutually insoluble. The classical procedure of such material fabrication includes preparation of a powder mixture followed by cold pressing and sintering of the mixture. Tin, zinc and lead additions enable sintering at presence of the liquid phase thus providing the possibility to achieve high compacting of these materials by free sintering. On the other hand, activating sintering additions markedly decrease the electrical conductivity of the examined material.

In the oder to reduce the unfavourable effect of the additions on the electrical conductivity we have prepared by hot isostatic pressing the coopergraphite based material which was free of activating sintering additions. For experimental works, electrolytical cooper with particles smaller than $70 \mu \mathrm{m}$ and graphite with particles smaller than $3 \mu \mathrm{m}$ and of $99.9 \%$ purity were enployed.The content of graphite in the coposite system was graded from 3 up to $40 \mathrm{vol} . \%$. The mentioned composite materials were subjected to complete examinations with focus on their structural and physical properties.
\end{abstract}


Obtained Results

The presence of graphite and its uniform distribution in the cooper matrix is well observable by optical microscopy. After hot isostatic pressing high compacting of composite materials was achieved in the $\mathrm{Cu}-\mathrm{C}$ composite system for all examined volume fractions of graphite. No residual porosity was observed. The high degree of compacting of the $\mathrm{Cu}-\mathrm{C}$ composite system was confirmed also by the results obtained from measuring the specific weights.

The resuts of the specific electrical resistance of the $\mathrm{Cu}-\mathrm{C}$ system are given in the following table

\begin{tabular}{|llll|}
\hline $\mathrm{n}_{\mathrm{M}}$ & $10^{4} \cdot \mathrm{v}_{\mathrm{M}}$ & $\mathrm{T}$ & $10^{8} . \mathrm{p}$ \\
{$[-]$} & {$\left[\mathrm{mg} \cdot \mathrm{g}^{-3} \mathrm{~kg}\right]$} & {$[\mathrm{K}]$} & {$[\Omega \cdot \mathrm{m}]$} \\
\hline
\end{tabular}

\begin{tabular}{|llll|}
\hline 0 & 1.15837 & $295.75+.01$ & $2.00597+.00857$ \\
0 & 1.15274 & $295.34+.02$ & $1.98295+.01419$ \\
0 & 1.16503 & $296.19+.11$ & $2.13551+.00206$ \\
0 & 1.18717 & $296.39+.11$ & $2.16840+.00036$ \\
0 & 1.16664 & $296.73+.09$ & $2.18727+.03813$ \\
0 & 1.11430 & $295.98+.05$ & $1.70246+.00372$ \\
0.0079 & 1.14595 & $296.08+.02$ & $1.84501+.00583$ \\
0.0079 & 1.15335 & $296.35+.08$ & $1.86151+.00105$ \\
0.0079 & 1.15630 & $296.39+.11$ & $1.84123+.00236$ \\
0.0079 & 1.15315 & $296.50+.11$ & $1.88201+.01637$ \\
0.0134 & 1.16083 & $296.43+.12$ & $1.89457+.00211$ \\
0.0134 & 1.17078 & $296.55+.11$ & $1.92344+.00249$ \\
0.0214 & 1.20743 & $296.73+.09$ & $2.11886+.00338$ \\
0.0214 & 1.20735 & $296.57+.14$ & $2.11992+.00133$ \\
0.0278 & 1.23567 & $296.72+.15$ & $2.30811+.00411$ \\
0.0278 & 1.22967 & $296.75+.16$ & $2.29209+.00103$ \\
0.0435 & 1.27332 & $296.91+.11$ & $2.67074+.03616$ \\
0.0605 & 1.31597 & $297.08+.13$ & $3.09914+.03130$ \\
0.0994 & 1.46327 & $296.99+.10$ & $4.64434+.02646$ \\
0.1217 & 1.54272 & $297.13+.09$ & $6.06951+.02382$ \\
0.1465 & 1.63049 & $297.24+.11$ & $7.19154+.01710$ \\
\hline
\end{tabular}

In the graphical representation of the obtained results the position $\mathbf{n}_{\mathrm{Mc}}$ is designated which separates the zone of carbon concentration for which the linear mixture rule is valid from the zone of carbon concetration in which the apparent percolation is observed. The $\mathrm{n}_{M c}$ value represents the experimentally assessed value of the percolating threshold for the $\mathrm{Cu}-\mathrm{C}$ system 


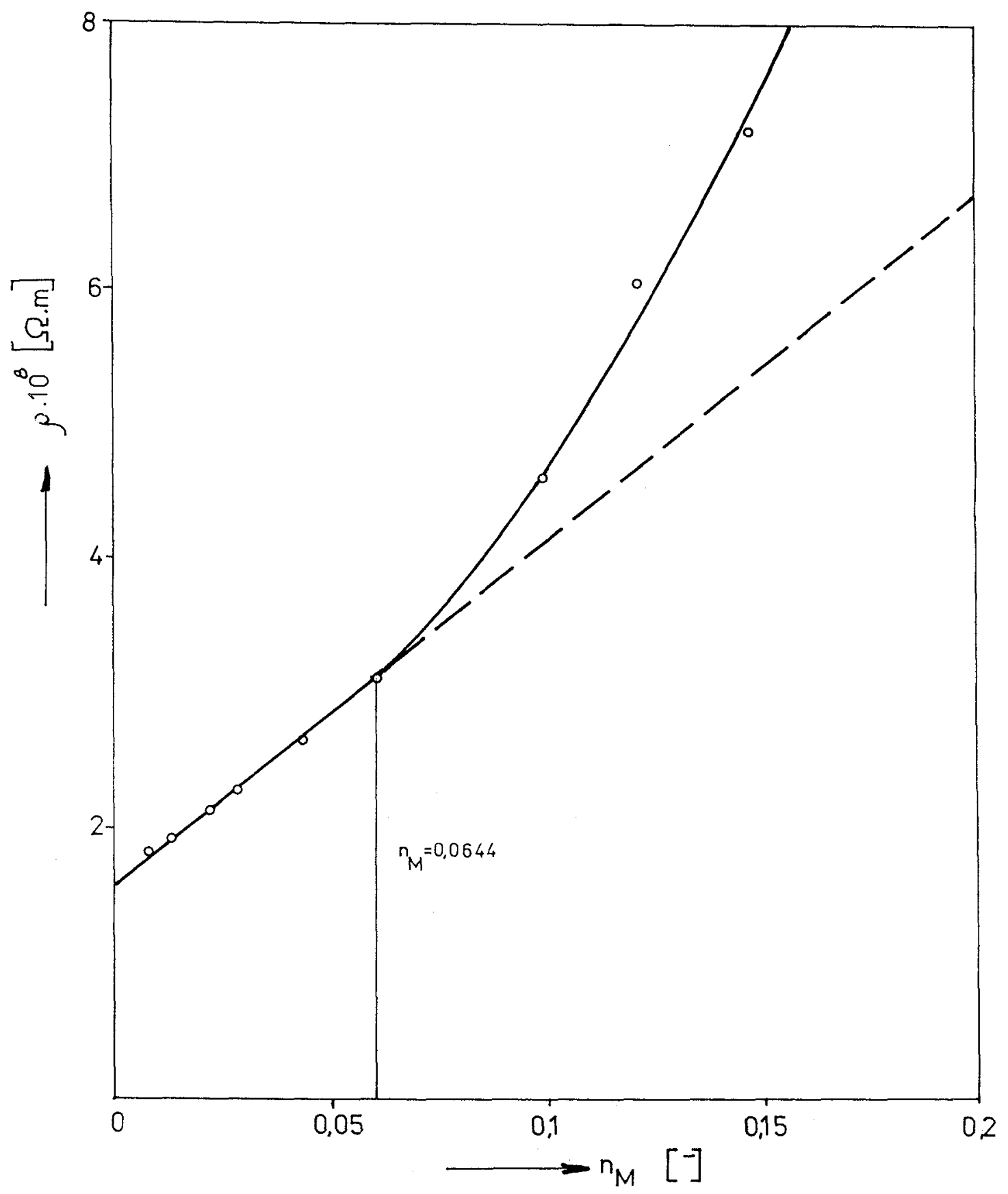

Experimental dependence of specific resistance as a function of the weight fraction $\mathrm{n}_{\mathrm{M}}$ for the $\mathrm{Cu}-\mathrm{C}$ system 

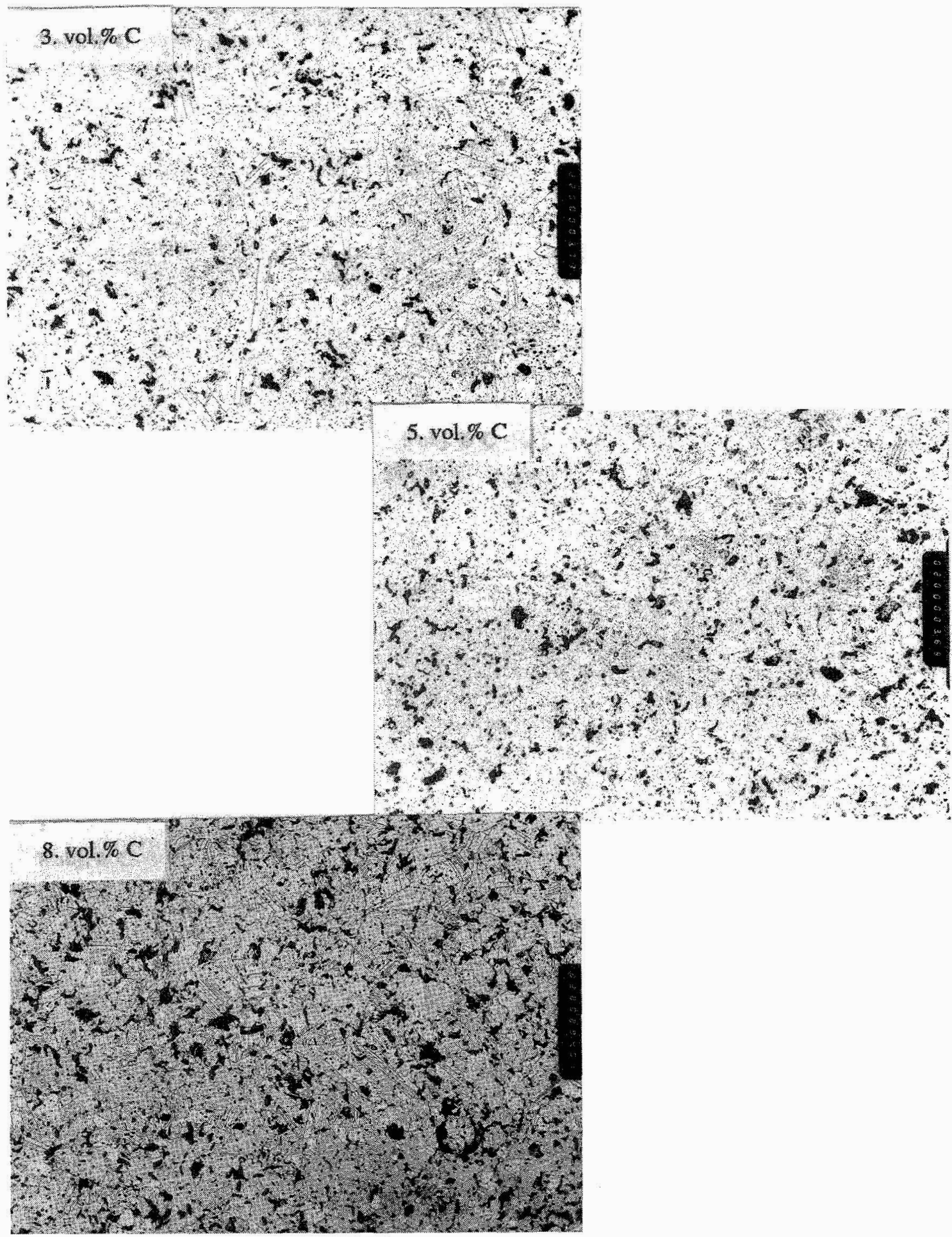

The structures of the cooper-graphite composite materials with different volume fraction of graphite 

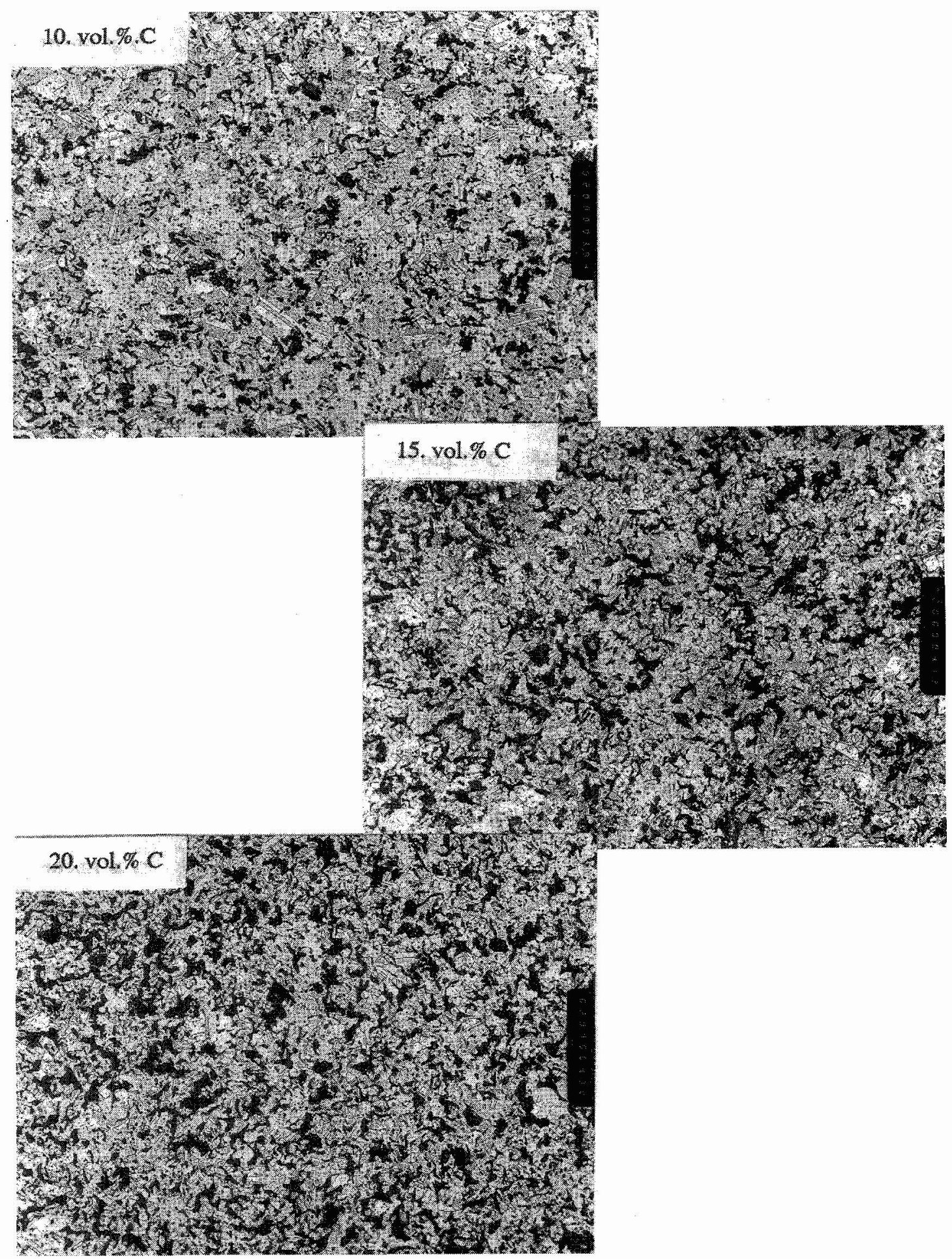

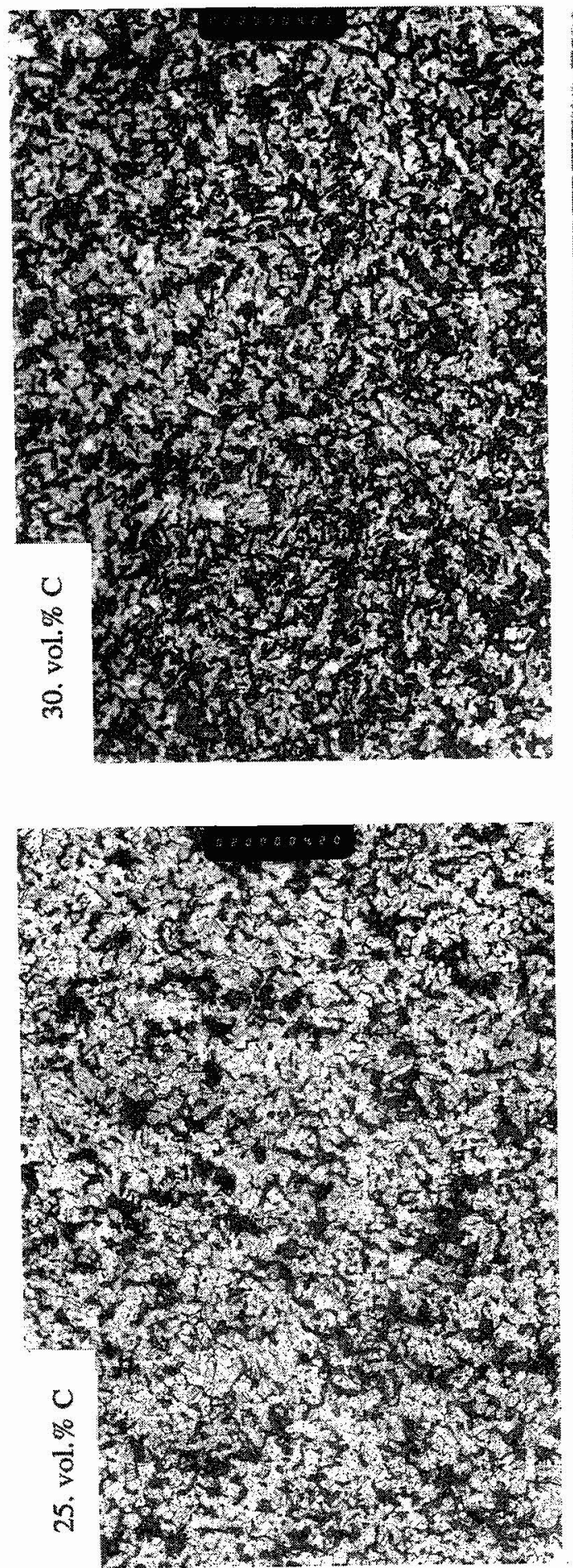
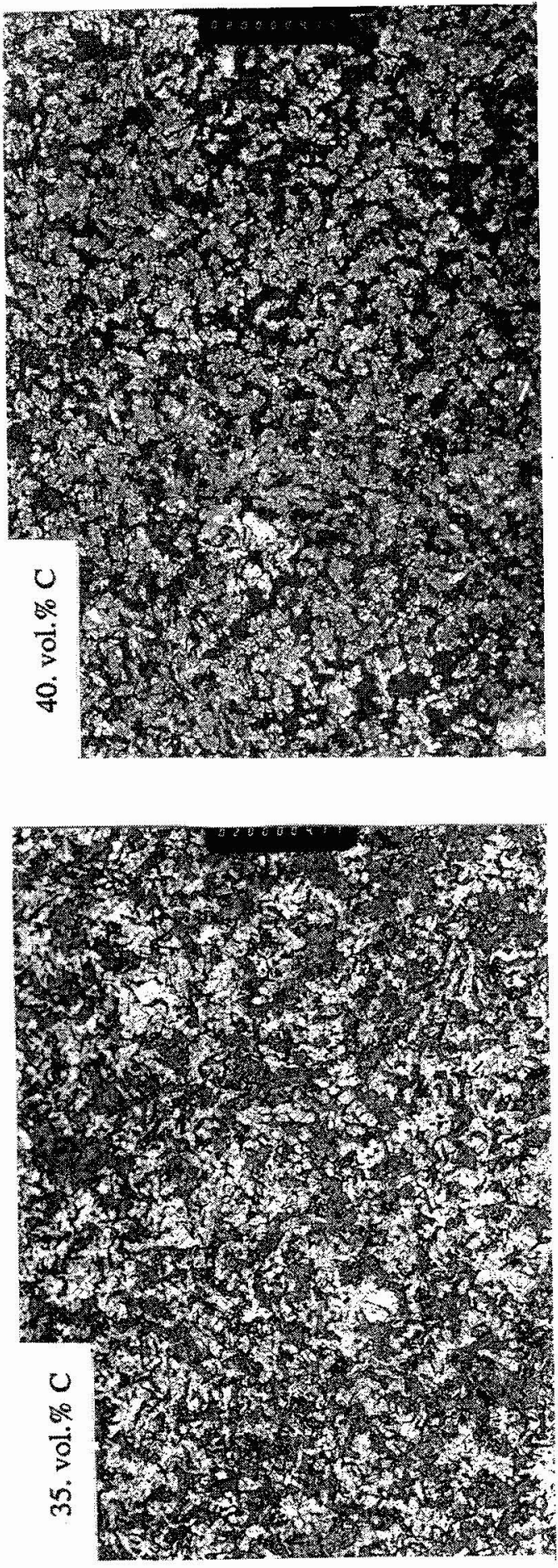